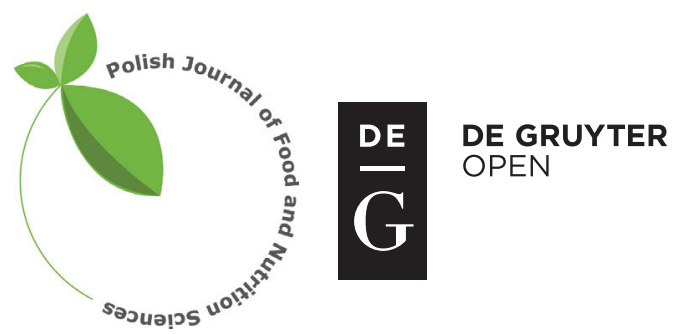

Pol. J. Food Nutr. Sci., 2018, Vol. 68, No. 3, pp. 217-222

DOI: $10.1515 /$ pjfns-2017-0030 http://journal.pan.olsztyn.pl

Original research article

Section: Food Quality and Functionality

\title{
Temperature Effect on Rheological Behavior of Portuguese Honeys
}

\author{
Maria João Afonso', Marta Magalhães ${ }^{2}$, Luana Fernandes ${ }^{2}$, Marina Castro ${ }^{2}$, Elsa C.D. Ramalhosa ${ }^{2 *}$ \\ ${ }^{I}$ ESTIG - Polytechnic Institute of Bragança, Campus de St a Apolónia, Apartado 1172, 5300-253 Bragança, Portugal \\ ${ }^{2}$ Centro de Investigação de Montanha (CIMO)/School of Agriculture, Polytechnic Institute \\ of Bragança, Campus de Sta Apolónia, 5300-253 Bragança, Portugal
}

Key words: honey, rheology, viscosity, temperature, Newtonian fluid

In the present work the temperature effect on rheological properties of Portuguese honeys was studied for the first time. Two unifloral honeys heather and rosemary - and a polyflower honey were analyzed. All honeys showed flow independence over time and behaved as Newtonian fluids at the studied temperature and shear rate ranges. For all honeys it was found that the viscosity decreased with temperature and the rosemary honey was the one that always presented the lowest viscosity at $30^{\circ} \mathrm{C}(6120 \mathrm{mPa} \cdot \mathrm{s}), 50^{\circ} \mathrm{C}(603 \mathrm{mPa} \cdot \mathrm{s})$ and $70^{\circ} \mathrm{C}(145 \mathrm{mPa} \cdot \mathrm{s})$. The temperature dependence of viscosity was well described by the $K_{0} \times e^{\frac{A}{T-B}}$ equation. Nevertheless, good regression coefficients were also obtained when fitting the experimental data to the Arrhenius model, showing the rosemary honey to be less temperature sensitive. The results obtained in this study are of great interest to beekeepers and industrials that handle and prepare eatable honey-based products because they will be better informed about the best type of honey to use.

\section{INTRODUCTION}

Rheological properties of honey are of particular interest to beekeepers and honey industrials because they affect handling, processing, storage, quality [Kayacier \& Karaman, 2008], and even honey consumption [Cohen \& Weihs, 2010]. The rheological properties of honey, as well as many other physical properties, depend on several factors, including the composition and temperature of the honey, with water content being one of the most important ones. Generally, honey viscosity decreases with the increase in water content [Bhandari et al., 1999a; Cohen \& Weihs, 2010; Gómez-Díaz et al., 2006; Lazaridou et al., 2004; Mossel et al., 2003; Tavakolipour \& Ashtari, 2010]. Furthermore, this parameter also influences honey quality and its storage time [Abu-Jdayil et al., 2002].

With regard to consistency, honey may be fluid, thick or partially or fully crystallized. As the market favors the sale of liquid honey [Kabbani et al., 2011], some types of treatment are necessary to keep honey in this state, such as filtration and heating. Heating is applied for several reasons, for example, to facilitate honey handling and packaging, retard the phenomenon of granulation and destroy microorganisms that may be present and adversely affect honey quality. Furthermore, heating might influence honey viscosity as stated by Kędzierska-Matysek et al. [2016], who observed that the dynamic viscosity of rape honey decreased substantially

\footnotetext{
* Corresponding Author: Tel.:+351 273 303308; Fax: +351 273303 319;

E-mail: elsa@ipb.pt
}

with an increase in temperature, being the effect of temperature more pronounced for temperatures up to $30^{\circ} \mathrm{C}$.

Several studies have been performed on the rheological characteristics of honeys from different countries, such as Australia [Bhandari et al., 1999b], Jordania [Al-Malah et al., 2001], Israel [Weihs, 2008], Poland [Witczak et al., 2011], and Persia [Tavakolipour \& Ashtari, 2010], among others. Regarding the flow properties of honey, dynamic rheological measurements revealed that the loss modulus $\left(G^{\prime \prime}\right)$ predominated over the storage modulus $\left(G^{\prime}\right)$ [Boussaid et al., 2015; Lazaridou et al., 2004; Oh \& Yoo, 2011; Smanalieva \& Senge, 2009; Sopade et al., 2004; Witczak et al., 2011; Yoo, 2004], confirming the viscous nature of honey and also indicating that honey seems to be similar to a liquid-like solution.

Beyond the countries mentioned above, Portugal is also an important honey producer, with beekeeping being an important income-generating activity in the rural communities located in the northeast of Portugal. However, to the best of our knowledge, no rheological studies on Portuguese honeys have been performed until now and the temperature effect on their rheological behavior is also unknown. Moreover, honey is generally used in the preparation of culinary dishes (e.g. sweets and candies) in several countries, which involves its treatment at high temperatures. In spite of this, the present study intended to obtain valuable data on the effect of temperature on the rheological behavior of Portuguese honeys, including their temperature-viscosity relationship. Moreover, when compared to other published studies on honey rheology, a broader temperature range $\left(30,50,70\right.$ and $\left.95^{\circ} \mathrm{C}\right)$ was applied. 


\section{MATERIAL AND METHODS}

\section{Material}

In this study, three different types of honey were analyzed. Two of them, heather and rosemary honeys, were of biological origin, from the Montesinho Natural Park. This Natural Park is located in Bragança district and is one of the largest protected areas in Portugal. The third honey was a polyflower honey from a beekeeper of Morais site. This village also belongs to Bragança district but it is not located in the Montesinho Natural Park. Morais site is a Natura 2000 Site (PTCON0023) and is an area of very high geological and botanical interest. This site has in its core the Morais Ophiolite Complex that is one of the most representative areas of ultramafic rocks, and the largest continuous unit of serpentine soils in Portugal. No study on the rheological behavior of Portuguese honeys and in particular those produced in the Montesinho Natural Park and Morais village has been performed so far.

The three types of honey studied in the present work were collected in distinct apiaries in 2011. At each apiary, three different samples were collected, with approx. $1 \mathrm{~kg} / \mathrm{sample}$. After their acquisition, the honey samples were immediately transported to the laboratory, where they were kept at room temperature (around $20^{\circ} \mathrm{C}$ ) in the dark.

\section{Determination of $\mathrm{pH}$, moisture and ash contents}

$\mathrm{pH}$ was directly determined in honey, using a portable $\mathrm{pH}$ meter Jenway 370 (United Kingdom), previously calibrated with buffer solutions of $\mathrm{pH} 7.01$ and 4.01, in a similar way as reported by Cohen \& Weihs [2010]. Moisture and ash contents of all honeys were calculated from the weight loss at $105 \pm 2{ }^{\circ} \mathrm{C}$ and $450 \pm 2{ }^{\circ} \mathrm{C}$ until constant weight, respectively. All measurements were done in triplicate.

\section{Rheological measurements}

To study the effect of temperature on honey rheological behavior, $10 \mathrm{~mL}$ of honey was placed in the container of the viscometer and heated at $30,50,70$ and $95^{\circ} \mathrm{C}$. For each honey, the temperature profiles for reaching these temperatures were determined. After $5 \mathrm{~min}$ of stabilization at the endpoint temperature, the shear stresses and viscosities were measured at fixed time intervals at different shear rates. The curves of loading and unloading were also assessed in order to verify a non-time dependent flow behavior. To measure the rheological properties of honey samples, a rotational, concentric cylinder viscometer (Visco Star plus, Fungilab, Spain), equipped with a temperature controller (Electro-Temp Fungilab), and the TL6 and TL7 spindles were used, with diameters equal to 1.18 and $0.94 \mathrm{~cm}$, respectively. The data acquisition was performed by the software "Data Logger vCli 1.01 ". The accuracy of the viscometer was tested with two Newtonian fluids, namely, glycerin and a vegetable oil. All measurements were done in triplicate.

\section{Data analysis}

As a non-time dependent flow behavior was observed, the experimental data were firstly described by the Herschel-Bulkley model:

$$
\sigma=\sigma_{O H B}+K \times \dot{\gamma}^{n}
$$

where: $\sigma$ is the shear stress $(\mathrm{Pa}), \sigma_{\text {OHB }}$ is the yield stress $(\mathrm{Pa})$, $K$ is the consistency coefficient $\left(\mathrm{Pa}_{\mathrm{Sec}}{ }^{\mathrm{n}}\right), \dot{\gamma}$ is the shear rate $(1 / \mathrm{sec})$ and $n$ is the flow behavior index (dimensionless). These rheological parameters were estimated by means of the MATLAB software, which also determined the 95\% confidence bounds of the rheological parameters and the goodness of the fits by the sum of squares due to error (SSE), R-square, adjusted R-square and the root mean squared error (RMSE).

Afterwards, the Ostwald-De Waele power law was also applied to the data:

$$
\tau=k \times(\dot{\gamma})^{n} \Leftrightarrow \ln \tau=\ln k+n \times \ln (\dot{\gamma})
$$

where: $k$ is the consistency coefficient $\left(\mathrm{Pa} \cdot \sec ^{\mathrm{n}}\right)$ and $n$ is the flow index (dimensionless). If a fluid is a Newtonian fluid, the flow index is equal to 1.0. If it is a pseudoplastic fluid, $n$ is less than 1, and if it is a dilatant fluid, $n$ will be higher than 1 .

The effect of temperature on honey apparent viscosity was analyzed by the Arrhenius relationship (3) and by the empirical equation (4), namely:

$$
\begin{aligned}
& \eta=K_{0} \times e^{\frac{E_{a}}{R T}} \\
& \eta=K_{0} \times e^{\frac{A}{T-B}}
\end{aligned}
$$

where: $\eta$ is the viscosity $(\mathrm{Pa} \cdot \mathrm{s}), K_{0}$ is a pre-exponent constant $(\mathrm{Pa} \cdot \mathrm{s}), E_{\mathrm{a}}$ is the activation energy $(\mathrm{J} / \mathrm{mol}), R$ is the universal gas constant $(8.314 \mathrm{~J} /(\mathrm{mol} \cdot \mathrm{K}))$ and $T$ is the absolute temperature $(\mathrm{K}) . A$ and $B$ are empirical constants and were estimated by the MATLAB software. The activation energy was obtained through Eq. (3) by plotting $\ln (\eta)$ versus $(1 / T)$. Furthermore, the SPSS Statistical software, v. 18.0 (SPSS Inc., Chicago, IL, USA) was used for the statistical treatment of moisture and ash data. Analysis of variance (ANOVA) was carried out to determine if there were significant differences $(p<0.05)$ between samples. Additionally, post hoc analysis was performed, namely the Tukey's honestly significant difference test.

\section{RESULTS AND DISCUSSION}

\section{Honeys characterization}

$\mathrm{pH}$, moisture and ash contents of the honeys studied in the present work are presented in Table 1. The $\mathrm{pH}$ values varied from 3.85 (polyflower honey) to 4.55 (heather honey), indicating that these three Portuguese honeys were acidic. These values were similar to those reported for Indian (3.8 to 5.0) [Ahmed et al., 2007], Turkish (3.67 to 4.57) [Kayacier \&Karaman, 2008], German (3.61 to 4.65) [Smanalieva \& Senge, 2009], and Israeli honeys (3.92 to 4.17) [Cohen \& Weihs, 2010].

In relation to moisture content, this is an important parameter that determines honey quality since it influences some honey characteristics, such as viscosity, weight, preservation, flavor, palatability, and crystallization. According to the Portuguese Law [Law-Decree No. 214/2003 of $18^{\text {th }}$ September], the maximum moisture content for honey is $20 \%$; however, for the heather honey a moisture content of $23 \%$ is allow- 
TABLE 1. pH value, moisture and ash contents in Portugese honeys.

\begin{tabular}{lccc}
\hline Honey & $\mathrm{pH}$ & $\begin{array}{c}\text { Moisture } \\
\text { content (\%) }\end{array}$ & $\begin{array}{c}\text { Ash } \\
\text { content (\%) }\end{array}$ \\
\hline $\begin{array}{l}\text { Heather } \\
\text { (Montesinho Natural Park) }\end{array}$ & 4.55 & $24.0 \pm 0.2^{\mathrm{a}}$ & $0.52 \pm 0.02^{\mathrm{a}}$ \\
$\begin{array}{l}\text { Rosemary } \\
\text { (Montesinho Natural Park) }\end{array}$ & 4.31 & $21.7 \pm 0.2^{\mathrm{b}}$ & $0.17 \pm 0.02^{\mathrm{b}}$ \\
$\begin{array}{l}\text { Polyflower } \\
\text { (Morais Village) }\end{array}$ & 3.85 & $16.5 \pm 1.6^{\mathrm{c}}$ & $0.093 \pm 0.002^{\mathrm{c}}$ \\
\hline
\end{tabular}

Data are presented as mean \pm standard deviations $(n=18)$. Values with the same letter in the same column are not statistically different $(p>0.05)$.

able. When comparing these values with those determined in the present study, it was observed that only the polyflower honey had a moisture content within the specified value. Due to the high moisture contents determined in heather and rosemary honeys, our results indicate that these honeys can undergo changes (e.g. undesirable fermentations) more quickly than polyflower honey, and these changes deteriorate their quality.

The ash content is directly related with the minerals content. The heather honey had the highest ash content $(0.52 \%)$. On the other hand, the polyflower and rosemary honeys were those with the lowest ash levels ( 0.093 and $0.17 \%$, respectively) and so the lowest mineral concentration. The range of ash content determined in the present work was similar to those reported to Turkish (from 0.11 to $0.52 \%$ ) [Kayacier \& Karaman, 2008] and Tunisian (from 0.06-0.58\%) [Boussaid et al., 2015] honeys.

\section{Honey rheological behavior}

Before determining the rheological behavior, the heating profiles of the three honeys were determined (Figure 1).

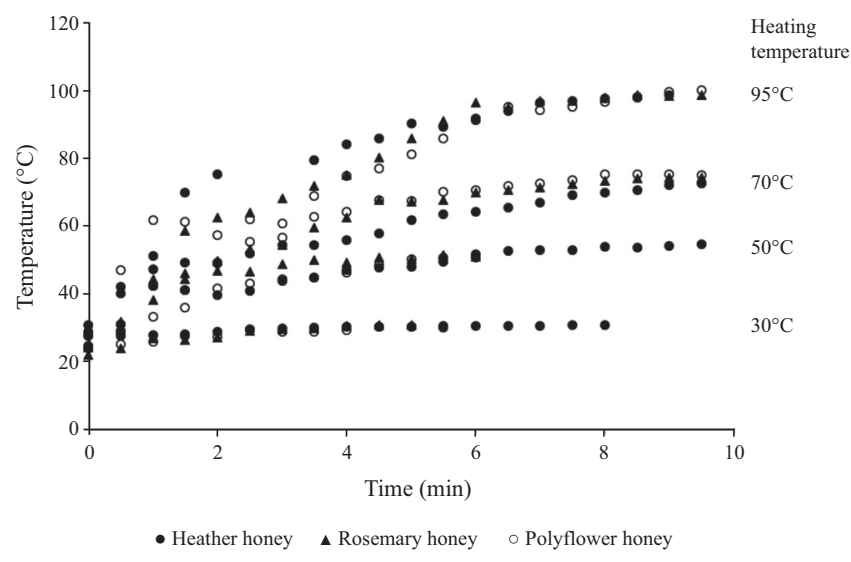

FIGURE 1. Temperature profiles of Portugese unifloral (heather and rosemary) and polyflower honeys.

At each temperature, all honeys showed a similar heating profile. As expected, the lowest periods of time required to reach the heating temperature were obtained at the lowest heating temperatures $\left(30\right.$ and $50^{\circ} \mathrm{C}$, respectively). However, the heating of the three honeys was very fast, even when high temperatures were applied. Furthermore, the polyflower honey with the lowest moisture content did not show a different heating profile when compared with the other two honeys. These results were different to those reported by Abu-Jdayil et al. [2002] for Jordan honeys who stated the longest time to reach the endpoint heating temperature for the honey with the lowest moisture content.

In relation to the rheological behavior, the shear stresses as function of shear rates at $30(\mathrm{~A}), 50(\mathrm{~B}), 70(\mathrm{C})$ and $95(\mathrm{D})^{\circ} \mathrm{C}$ for the three honeys studied in the present work are represent-
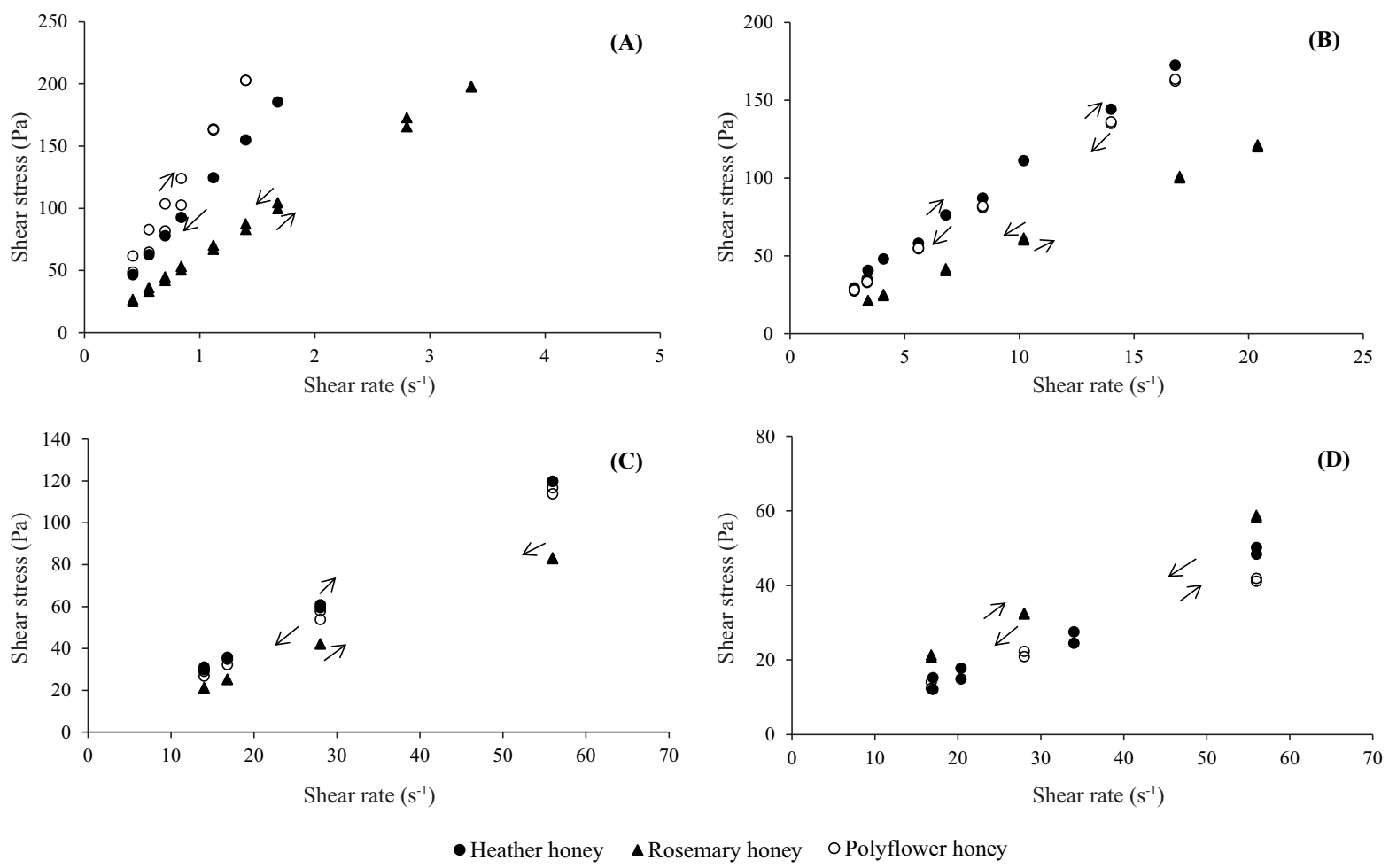

FIGURE 2. Shear stress as a function of shear rate at 30 (A), 50 (B), 70 (C), and $95^{\circ} \mathrm{C}$ (D) of Portugese heather, rosemary and polyflower honeys. 
TABLE 2. Herschel-Bulkley model parameters determined for Portuguese honeys heated at different temperatures.

\begin{tabular}{|c|c|c|c|c|c|}
\hline Honey & $\begin{array}{l}\text { Temperature } \\
\left({ }^{\circ} \mathrm{C}\right)\end{array}$ & $\begin{array}{c}\text { Yield } \\
\text { stress }\left(\sigma_{0 \mathrm{OB}}\right) \\
(\mathrm{Pa}) \\
\end{array}$ & $\begin{array}{c}\text { Consistency } \\
\text { coefficient }(\mathrm{K}) \\
\left(\mathrm{Pa} \cdot \mathrm{sec}^{\mathrm{n}}\right) \\
\end{array}$ & $\begin{array}{c}\text { Flow } \\
\text { behavior } \\
\text { index (n) (-) }\end{array}$ & R-square \\
\hline \multirow{4}{*}{ Heather } & 30 & $\begin{array}{c}-0.64 \\
(-6.04,4.75)\end{array}$ & $\begin{array}{c}112 \\
(106,117)\end{array}$ & $\begin{array}{c}0.988 \\
(0.936,1.04)\end{array}$ & 1.00 \\
\hline & 50 & $\begin{array}{c}-4.51 \\
(-24.29,-15.26)\end{array}$ & $\begin{array}{c}14.0 \\
(4.49,23.5)\end{array}$ & $\begin{array}{c}0.898 \\
(0.690,1.11)\end{array}$ & 0.997 \\
\hline & 70 & $\begin{array}{c}0.60 \\
(-7.31,8.50)\end{array}$ & $\begin{array}{c}2.10 \\
(0.90,3.3)\end{array}$ & $\begin{array}{c}1.00 \\
(0.877,1.13)\end{array}$ & 1.00 \\
\hline & 95 & $\begin{array}{c}8.42 \\
(-0.38,17.22) \\
\end{array}$ & $\begin{array}{c}0.05 \\
(-0.13,0.23) \\
\end{array}$ & $\begin{array}{c}1.68 \\
(0.786,2.56) \\
\end{array}$ & 0.990 \\
\hline \multirow{4}{*}{ Rosemary } & 30 & $\begin{array}{c}-2.22 \\
(-10.37,5.93)\end{array}$ & $\begin{array}{c}63.9 \\
(55.1,72.7)\end{array}$ & $\begin{array}{c}0.950 \\
(0.860,1.04)\end{array}$ & 0.998 \\
\hline & 50 & $\begin{array}{c}1.1 \\
(-1.54,3.74)\end{array}$ & $\begin{array}{c}5.84 \\
(4.86,6.81)\end{array}$ & $\begin{array}{c}1.00 \\
(0.952,1.05)\end{array}$ & 1.00 \\
\hline & 70 & $\begin{array}{c}-1.08 \\
(-3.53,1.37)\end{array}$ & $\begin{array}{c}1.75 \\
(1.33,2.17)\end{array}$ & $\begin{array}{c}0.962 \\
(0.910,1.01)\end{array}$ & 1.00 \\
\hline & 95 & $\begin{array}{c}0.13 \\
(-9.25,9.52) \\
\end{array}$ & $\begin{array}{c}1.89 \\
(-0.08,3.87) \\
\end{array}$ & $\begin{array}{c}0.852 \\
(0.631,1.07) \\
\end{array}$ & 1.00 \\
\hline \multirow{4}{*}{ Polyflower } & 30 & $\begin{array}{c}4.32 \\
(-64.4,73.0)\end{array}$ & $\begin{array}{c}136 \\
(60,211)\end{array}$ & $\begin{array}{c}1.15 \\
(0.432,1.88)\end{array}$ & 0.976 \\
\hline & 50 & $\begin{array}{c}1.09 \\
(-1.06,3.24)\end{array}$ & $\begin{array}{c}9.40 \\
(8.50,10.3)\end{array}$ & $\begin{array}{c}1.01 \\
(0.978,1.04)\end{array}$ & 1.00 \\
\hline & 70 & $\begin{array}{c}3.32 \\
(-13.37,20.02)\end{array}$ & $\begin{array}{c}1.38 \\
(-0.64,3.41)\end{array}$ & $\begin{array}{c}1.09 \\
(0.762,1.42)\end{array}$ & 0.998 \\
\hline & 95 & $\begin{array}{c}-0.67 \\
(-21.08,19.74) \\
\end{array}$ & $\begin{array}{c}1.04 \\
(-2.56,4.63) \\
\end{array}$ & $\begin{array}{c}0.921 \\
(0.175,1.667) \\
\end{array}$ & 0.997 \\
\hline
\end{tabular}

The values inside the parenthesis correspond to the coefficients with $95 \%$ confidence bounds.

ed in Figure 2. Almost all studied honeys showed Newtonian flow because linear relationships were observed between shear stress and shear rate, passing the lines through the y-axis origin. Furthermore, no dependence of the flow over time was detected because the loading and unloading curves overlapped. This meant that no thixotropy was observed. The lowest slopes of the lines were always detected for the rosemary honey at almost all temperatures (with exception at $95^{\circ} \mathrm{C}$ ), suggesting a honey with lower viscosity than the others.
The Herschel-Bulkley model was applied to the data, being the rheological parameters indicated in Table 2. As the yield stresses (parameter that indicates when the material behavior changes from elastic to viscous) determined in the present work were low (less than $8.5 \mathrm{~Pa}$ and all 95\% confidence intervals included the zero number), it indicated an insignificant effect of microparticles (crystals) in honey [Smanalieva \& Senge, 2009]. Moreover, the negative values of the yield stresses indicate modelling error because

TABLE 3. Power Law model parameters determined for Portuguese honeys heated at different temperatures and 95\% confidence interval for the slope.

\begin{tabular}{l|c|c|c}
\hline Sample & Temperature $\left({ }^{\circ} \mathrm{C}\right)$ & $\operatorname{Ln} \tau=\mathrm{n} \ln \gamma+\ln \mathrm{K}$ & 95\% Confidence interval for the slope \\
\hline \multirow{3}{*}{ Heather } & 30 & $\operatorname{Ln} \tau=0.996 \ln \gamma+4.71(\mathrm{r}=1.00)$ & 0.986 to 1.00 \\
& 50 & $\operatorname{Ln} \tau=0.963 \ln \gamma+2.44(\mathrm{r}=0.996)$ & 0.962 to 1.02 \\
& 70 & $\operatorname{Ln} \tau=0.992 \ln \gamma+0.790(\mathrm{r}=1.00)$ & 0.893 to 1.19 \\
\hline & 95 & $\operatorname{Ln} \tau=1.042 \ln \gamma-0.354(\mathrm{r}=0.985)$ & 0.958 to 1.014 \\
Rosemary & 30 & $\operatorname{Ln} \tau=0.986 \ln \gamma+4.113(\mathrm{r}=0.999)$ & 0.965 to 0.989 \\
& 50 & $\operatorname{Ln} \tau=0.977 \ln \gamma+1.843(\mathrm{r}=1.00)$ & 0.978 to 1.139 \\
\hline & 70 & $\operatorname{Ln} \tau=1.058 \ln \gamma+0.206(\mathrm{r}=0.991)$ & 0.821 to 0.876 \\
\hline \multirow{3}{*}{ Polyflower } & 95 & $\operatorname{Ln} \tau=0.849 \ln \gamma+0.653(\mathrm{r}=1.00)$ & 0.939 to 1.27 \\
& 30 & $\operatorname{Ln} \tau=1.105 \ln \gamma+4.94(\mathrm{r}=0.978)$ & 0.984 to 0.998 \\
& 50 & $\operatorname{Ln} \tau=0.991 \ln \gamma+2.30(\mathrm{r}=1.00)$ & 1.006 to 1.090 \\
\hline
\end{tabular}


TABLE 4. Viscosities (mPa.s) of the analyzed heather, polyflower and rosemary honeys.

\begin{tabular}{c|c|c}
\hline Honey & Temperature $\left({ }^{\circ} \mathrm{C}\right)$ & Viscosity $(\mathrm{mPa} \cdot \mathrm{s})$ \\
\hline \multirow{3}{*}{ Heather } & 30 & $11085 \pm 50$ \\
& 50 & $1088 \pm 68$ \\
& 70 & $216 \pm 4$ \\
& 95 & $78 \pm 7$ \\
\hline \multirow{3}{*}{ Rosemary } & 30 & $6120 \pm 202$ \\
& 50 & $603 \pm 13$ \\
& 70 & $145 \pm 8$ \\
Polyflower & 95 & $115 \pm 9$ \\
\hline \multirow{5}{*}{$*$} & 30 & $13678 \pm 1435$ \\
& 50 & $975 \pm 9$ \\
& 70 & $198 \pm 9$ \\
& 95 & $74 \pm 4$ \\
\hline
\end{tabular}

Data are presented as mean \pm standard deviations $(n=18)$.

it is physically impossible. Generally, the flow behavior index and yield stress were always around 1.0 and 0.0 , respectively, suggesting a Newtonian flow. These results were confirmed by Ostwald-de Waele power law (Table 3). High linear correlation coefficients were obtained (0.978 to 1.00$)$ and all slopes were around 1.0, indicating a Newtonian flow. Only the rosemary honey at $95^{\circ} \mathrm{C}$ showed a slope lower than 1 , indicating a slight shear thinning flow behavior; however, this behavior might be due to some experimental errors (instrumental drift).

The viscosity values obtained for the three honeys studied at $30,50,70$ and $95^{\circ} \mathrm{C}$ remained constant with the shear rate most of the time, corroborating the Newtonian flow behavior (Table 4). A similar rheological behavior has also been reported for Chinese honeys subjected to a temperature range from 10 to $30^{\circ} \mathrm{C}$ [Junzheng \& Changying, 1998], Australian honeys treated at 4 to $30^{\circ} \mathrm{C}$ [Bhandari et al., 1999a] and at subzero temperatures [Sopade et al., 2004], Jordan honeys treated at 40 to $94^{\circ} \mathrm{C}$ [Abu-Jdayil et al., 2002], non-irradiated and gamma irradiated Brazilian honeys [Sabato, 2004], Greek honeys subjected to heat treatment from 20 to $60^{\circ} \mathrm{C}$ [Lazaridou et al., 2004], Polish honeys heat-treated from 10 to $40^{\circ} \mathrm{C}$ [Juszczak \& Fortuna, 2006], Turkish honey samples from 10 to $40^{\circ} \mathrm{C}$ [Kayacier \& Karaman, 2008], Mexican honeys up to the $12^{\text {th }}$ storage week [Mora-Escobedo et al., 2006], Israeli floral honeys from 5 to $40^{\circ} \mathrm{C}$ [Cohen \& Weihs, 2010; Weihs, 2008], two Persian honeys from 10 to $30^{\circ} \mathrm{C}$ [Tavakolipour $\&$ Ashtari, 2010], and a Spanish rosemary honey from 40 to $60^{\circ} \mathrm{C}$ [Kabbani et al., 2011]. On the other hand, Gómez-Díaz et al. [2006] observed pseudoplastic behavior in Galician honeys treated at $25^{\circ} \mathrm{C}$, as well as Smanalieva \& Senge [2009], Witczak et al. [2011] and Boussaid et al. [2015] who also reported non-Newtonian behavior for unifloral German honeys $\left(10\right.$ to $\left.50^{\circ} \mathrm{C}\right)$, Polish heather honeys $\left(10\right.$ to $\left.40^{\circ} \mathrm{C}\right)$ and six Tunisian honeys $\left(20^{\circ} \mathrm{C}\right)$, respectively. Nevertheless the Portuguese honeys analyzed did not show such a behavior.

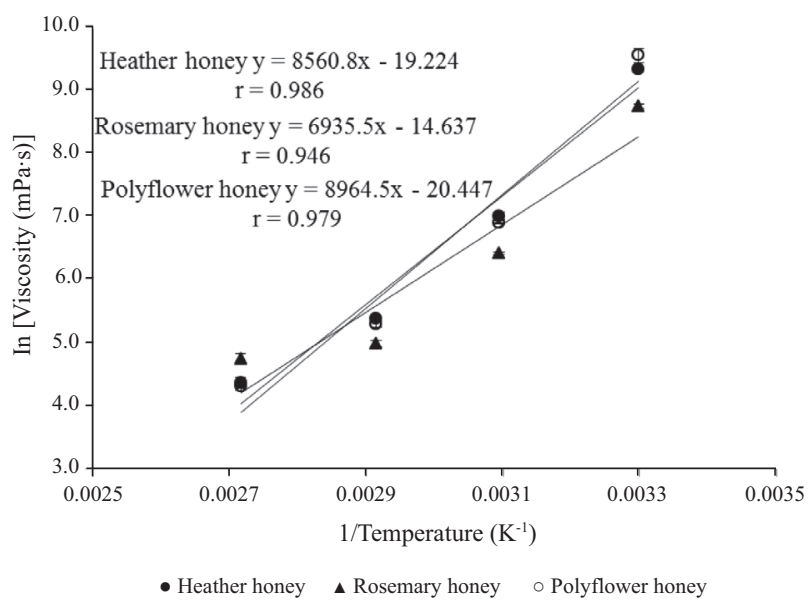

FIGURE 3. Arrhenius model determined for Portugese heather, rosemary and polyflower honeys.

TABLE 5. $K_{0} \times e^{\frac{A}{T-B}}$ model parameters determined for the three analyzed Portuguese honeys.

\begin{tabular}{lccccc}
\hline Honey & $\mathrm{K}_{0}(\mathrm{mPa} \cdot \mathrm{s})$ & $\mathrm{A}$ & $\mathrm{B}$ & R-square \\
\hline \multirow{2}{*}{ Heather } & 0.0838 & 961 & 222 & \multirow{2}{*}{1.000} \\
\multirow{4}{*}{ Rosemary } & $(-1.62,1.79)$ & $(-2808,4731)$ & $(43 ; 401)$ & \\
\multirow{5}{*}{ Polyflower } & $(-105.9 ;$ & 304 & 261 & 0.9999 \\
& 0.534 & $(-2344 ; 2951)$ & $(37 ; 485)$ & \\
& $(-4.65 ; 5.72)$ & $(-739 ; 1893)$ & $(171 ; 322)$ & 1.000 \\
\hline
\end{tabular}

The values inside the parenthesis correspond to the coefficients with $95 \%$ confidence bounds.

Concerning honey heating, for all cases it was found that the viscosity decreased with temperature (Table 4). Rosemary honey was the one that always presented the lowest viscosity at 30,50 and $70^{\circ} \mathrm{C}$. Nevertheless, this honey did not have the highest moisture content. Generally, honeys with high moisture contents present low viscosities [Witczak et al., 2011] due to the plasticizing effect of water. Thus, the present results indicated that other components affect honey viscosity. Regarding the polyflower honey, its behavior was more similar to the heather honey than to the rosemary honey.

Arrhenius equation is commonly used to describe the viscosity-temperature relationship for honey. The parameters of this equation describing the viscosity-temperature relationship were determined by linear regression $(\ln$ viscosity $=f(1 / \mathrm{T})$ ) and are indicated in Figure 3. Linear correlation coefficients between 0.946 and 0.986 were obtained. The values of activation energy ( $\mathrm{E}_{\mathrm{a}}$ ) were equal to $71.2,57.7$ and $74.5 \mathrm{~kJ} / \mathrm{mol}$ for the heather, rosemary and polyflower honeys, respectively. This parameter reflects the sensitivity of viscosity to temperature changes [Juszczak \& Fortuna, 2006; Lazaridou et al., 2004], showing that the rosemary honey was the least sensitive (lowest $\mathrm{E}_{\mathrm{a}}$ value) among the three studied honeys. The activation energies determined in the present work were similar to those reported by Lazaridou et al. [2004] for Greek honeys (69.1 to $93.75 \mathrm{~kJ} / \mathrm{mol})$, Kayacier \& Karaman [2008] for Turkish honeys (63.4 to $78.5 \mathrm{~kJ} / \mathrm{mol}$ ), and Gómez-Díaz et al. [2009] (83.8 to $96.3 \mathrm{~kJ} / \mathrm{mol}$ ) and Kabbani et al. [2011] (64 kJ/ 
mol) for Spanish honeys. Nevertheless, as a slight curvature was observed in the data, the Equation (4) was applied to the viscosity values, being high coefficients of determination $\left(\mathrm{R}^{2}\right)$ obtained (Table 5), varying between 0.9999 and 1.000. These results showed that the model expressed by Equation (4) gave a better fit than the Arrhenius equation.

\section{CONCLUSIONS}

Over the temperature range from 30 to $95^{\circ} \mathrm{C}$, the Portuguese heather, rosemary and polyflower honeys analyzed in the present work exhibited the Newtonian behavior. Heating caused a reduction in viscosity; however, heather and polyflower honeys seemed to be more sensitive to temperature than rosemary honey. Furthermore, the equation $K_{0} \times e^{\frac{A}{T-B}}$ described successfully the temperature dependence of viscosity. Thus, the present study has a significant practical importance because it gives valuable information to beekeepers and industrials that handle and prepare eatable honey-based products subjected to heat treatment.

\section{RESEARCH FUNDING}

The authors are grateful to the Foundation for Science and Technology (FCT, Portugal) and FEDER under Programme PT2020 for financial support to CIMO (UID/ AGR/00690/2013).

\section{CONFLICT OF INTEREST STATEMENT}

The authors declare not to have any conflict of interest.

\section{REFERENCES}

1. Abu-Jdayil B., Ghzawi A.A.-M., Al-Malah K.I.M., Zaitoun S., Heat effect on rheology of light- and dark-colored honey. J. Food Eng., 2002, 51, 33-38.

2. Ahmed J., Prabhu S.T., Raghavan G.S.V., Ngadi M., Physicochemical, rheological, calorimetric and dielectric behavior of selected Indian honey. J. Food Eng., 2007, 79, 1207-1213.

3. Al-Malah K., Abu-Jdayil B., Zaitoun S., Ghzawi A.A.M., Application of WLF and Arrhenius kinetics to rheology of selected dark-colored honey. J. Food Process., 2001, 24, 341-357.

4. Bhandari B., D’Arcy B., Kelly C., Rheology and crystallization kinetics of honey: present status. Int. J. Food Prop., 1999a, 2, 217-226.

5. Bhandari B., D'Arcy B., Chow S., Rheology of selected Australian honeys. J. Food Eng., 1999b, 41, 65-68.

6. Boussaid A., Chouaibi M., Rezig L., Missaoui R., Donsí F., Ferrari G., Hamdi S., Physicochemical, rheological, and thermal properties of six types of honey from various floral origins in Tunisia. Int. J. Food Prop., 2015, 18, 2624-2637.

7. Cohen I., Weihs D., Rheology and microrheology of natural and reduced-calorie Israeli honeys as a model for high-viscosity Newtonian liquids. J. Food Eng., 2010, 100, 366-371.

8. Gómez-Díaz D., Navaza J.M., Quintáns-Riveiro L.C., Rheological behaviour of Galician honeys. Eur. Food Res. Technol., 2006, 222, 439-442.
9. Gómez-Díaz D., Navaza J.M., Quintáns-Riveiro L.C., Effect of temperature on the viscosity of honey. Int. J. Food Prop., 2009, 12, 396-404.

10. Junzheng P., Changying J., General rheological model for natural honeys in China. J. Food Eng., 1998, 36, 165-168.

11. Juszczak L., Fortuna T., Rheology of selected Polish honeys. J. Food Eng., 2006, 75, 43-49.

12. Kabbani D., Sepulcre F., Wedekind J., Ultrasound-assisted liquefaction of rosemary honey: Influence on rheology and crystal content. J. Food Eng., 2011, 107, 173-178.

13. Kayacier A., Karaman S., Rheological and some physicochemical characteristics of selected Turkish honeys. J. Texture Stud., 2008, 39, 17-27.

14. Kędzierska-Matysek M., Florek M., Wolanciuk A., Skałecki P., Litwińczuk A., Characterisation of viscosity, colour, 5-hydroxymethylfurfural content and diastase activity in raw rape honey (Brassica napus) at different temperatures. J. Food Sci. Technol., 2016, 53, 2092-2098.

15. Law-Decree No. 214/2003 of $18^{\text {th }}$ September. Diário da República - I Série-A, N. ${ }^{\circ} 216$ - 18 de Setembro de 2003, pp. 6057-6060 (in Portuguese).

16. Lazaridou A., Biliaderis C.G., Bacandritsos N., Sabatini A.G., Composition, thermal and rheological behaviour of selected Greek honeys. J. Food Eng., 2004, 64, 9-21.

17. Mora-Escobedo R., Moguel-Ordóñez Y., Jaramillo-Flores M.E., Gutiérrez-López G.F., The composition, rheological and thermal properties of Tajonal (Viguiera dentata) Mexican honey. Int. J. Food Prop., 2006, 9, 299-316.

18. Mossel B., Bhandari B., D’Arcy B., Caffin N., Determination of viscosity of some Australian honeys based on composition. Int. J. Food Prop., 2003, 6, 87-97.

19. Oh J.-H., Yoo B., Effect of temperature on the relationship between moisture content and dynamic rheological properties of Korean honey. Food Sci. Biotechnol., 2011, 20, 261-265.

20. Sabato S.F., Rheology of irradiated honey from Parana region. Radiat. Phys. Chem., 2004, 71, 99-102.

21. Smanalieva J., Senge B., Analytical and rheological investigations into selected unifloral German honey. Eur. Food Res. Tecnhol., 2009, 229, 107-113.

22. Sopade P.A., Halley P.J., D’Arcy B.R., Bhandary B., Caffin N., Dynamic and steady-state rheology of Australian honeys at subzero temperatures. J. Food Process. Eng., 2004, 27, 284-309.

23. Tavakolipour H., Ashtari A.K., Rheology of selected Persian honeys. Int. J. Food Eng., 2010. 6(3), Article number 16 (DOI: 10.2202/1556-3758.1799).

24. Weihs D., Effects of sugar content and temperature on rheology and microrheology of Israeli honey. 2008, in: AIP Conference Proceedings, XV International Congress on Rheology: The Society of Rheology 80th Annual Meeting (eds. A. Co, G.L. Leal). Monterey, USA, pp. 1238-1240.

25. Witczak M., Juszczak L., Galkowska D., Non-Newtonian behaviour of heather honey. J. Food Eng., 2011, 104, 532-537.

26. Yoo B., Effect of temperature on dynamic rheology of Korean honeys. J. Food Eng., 2004, 65, 459-463.

Submitted: 24 March 2017. Revised: 23 June and 7 September 2017. Accepted: 19 September 2017. Published on-line: 07 February 2018. 